\title{
PENGARUH PEMBERIAN PLANT GROWTH PROMOTING RHIZOBACTERIA (PGPR) AKAR BAMBU PADA PERTUMBUHAN DAN PRODUKSI TANAMAN PAKCOY (Brassica rapa L.)
}

\section{Effect of Plant Growth Promoting Rhizobacteria (PGPR) Bamboo Roots On Growth and Production of Pakcoy Plants (Brassica rapa L.)}

\author{
Rachmat, Ramli, Abd. Azis H., dan Sendi Bororing \\ Jurusan Pertanian, Politeknik Pembangunan Pertanian Gowa \\ e-mail: sumarmanrachmat@gmail.com
}

Received: 10 Februari 2021; Accepted: 28 Mei 2021; Published: 25 Juni 2021

\begin{abstract}
ABSTRAK
Penelitian ini bertujuan untuk mengetahui pengaruh pemberian plant growth promoting rhizobacteria (PGPR) akar bambu pada pertumbuhan dan produksi tanaman pakcoy (Brassica rapa L.). Penelitian ini dilaksanakan dengan menggunakan metode yang digunakan dalam kajian ini yakni Rancangan Acak Kelompok (RAK) yang terdiri dari 4 perlakuan dan 3 ulangan, sehingga terdapat 12 plot. Dalam pelaksanaan kajian 1 plot terdapat 25 tanaman total tanaman untuk keseluruhan adalah 300 tanaman. Pengamatan dilakukan untuk memperoleh data yang akan dianalisis. Pengambilan data dilakukan 1 minggu setelah tanaman diberikan PGPR akar bambu dengan cara mengukur pertumbuhan tanaman dengan menggunakan alat ukur berupa mistar. Pengambilan data dilakukan pada saat tanaman berumur 7, 14, 21, dan 28 (HST), dilakukan sesuai dengan parameter yang diteliti, yaitu tinggi tanaman, jumlah daun, dan berat basah. rata-rata tinggi tanaman pakcoy mengalami peningkatan pada umur 7, 14, 21 dan 28 hari setelah tanam. rata-rata jumlah daun pakcoy yang diamati mengalami peningkatan pada umur 7, 14, 21 dan, 28 hari setelah tanam. rata-rata berat basah tanaman pakcoy umur 45 hari setelah tanam tidak mengalami perubahan.
\end{abstract}

Kata kunci: PGPR, pertumbuhan, produksi, tanaman pakcoy

\section{PENDAHULUAN}

Indonesia terletak di daerah tropis yang memiliki dua musim yakni musim kemarau dan musim penghujan, sehingga memungkinkan untuk mengembangkan berbagai jenis komoditas hortikultura. Laju peningkatan produksi tanaman sayuran di Indonesia berkisar antara 2,4-7,7\% setiap tahun (Suwandi,2009). Diantara berbagai macam jenis sayuran yang dapat di budidayakan di Indonesia, sawi merupakan salah satu komoditas yang memiliki nilai komersial yang cukup tinggi. Morfologi yang cukup menarik dari sawi pakcoy (Brassica rapa L.) membuat tanaman tersebut banyak digunakan dalam berbagai jenis masakan. Hal tersebut memberikan prospek cerah bagi petani pakcoy.

Bakteri perakaran pemacu tumbuh tanaman yang lebih popular disebut Plant Growth Promotiong Rhizobacteria (PGPR) merupakan kelompok bakteri menguntungkan yang secara aktif mengkolonisasi rhizosfir. PGPR berperan penting dalam meningkatkan pertumbuhan tanaman, hasil panen dan kesuburan lahan (Wahyudi, 2009). Salah satu formula PGPR yang diintroduksi ke pertanaman budidaya dapat bersumber dari perakaran bambu, rumput gajah, serai dan putri malu. PGPR yang bersumber pada akar rumpun bambu, rumput gajah, serai yang mengandung bakteri Pseudomonas flourenscens, Bacillus polymixa (Iswati, 2012).

Keuntungan penggunaan PGPR adalah meningkatkan toleransi tanaman terhadap cekaman lingkungan, sebagai biofertiliser, agen biologi control, melindungi tanaman dari pathogen tumbuhan serta peningkatan produksi Indol-3-Acetic Acid (IAA) (Figueiredo dll, 2010). Tanaman pakcoy termasuk tanaman yang berumur pendek dan memiliki kandungan gizi 
yang diperlukan tubuh. Kandungan betakaroten pada pakcoy dapat mencegah penyakit katarak. Selain mengandung betakaroten yang tinggi, pakcoy juga mengandung banyak gizi diantaranya protein, lemak nabati, karbohidrat, serat, $\mathrm{Ca}, \mathrm{Mg}$, Fe, sodium, vitamin A dan vitamin C. (Prasasti dkk, 2014).

\section{METODE PENELITIAN}

\section{Tempat dan Waktu}

Penelitian dilaksanakan di Kelurahan Lansot, Kecamatan Tomohon Selatan, Kota Tomohon yaitu mulai minggu kedua bulan April sampai dengan minggu pertama bulan Juni 2020 dan lokasi penyuluhan dilaksanakan di kelompok tani Masawasawangan Kelurahan Lansot, Kecamatan Tomohon Selatan, Kota Tomohon, Provinsi Sulawesi Utara.

\section{Alat dan Bahan}

Alat yang digunakan yaitu: cangkul, gembor, spidol, gunting, tali, meteran, timbangan, ember, selang, pengaduk, saringan. Alat yang digunakan dalam pelaksanaan penyuluhan yaitu kamera, peta singkap.

Bahan-baham yang digunakan adalah tanah, arang bakar, benih pakcoy panah merah, akar bambu $100 \mathrm{~g}, 500 \mathrm{~g}$ gula merah, $100 \mathrm{~g}$ terasi, $1 \mathrm{~kg}$ dedak halus, 20 liter air. Bahan untuk penyuluhan yaitu: kuesioner, dan materi penyuluhan.

\section{Rancangan Penelitian}

Penelitian ini dilaksanakan dengan menggunakan metode yang digunakan dalam kajian ini yakni Rancangan Acak Kelompok (RAK) yang terdiri dari 4 perlakuan dan 3 ulangan, sehingga terdapat 12 plot. Dalam pelaksanaan kajian 1 plot terdapat 25 tanaman total tanaman untuk keseluruhan adalah 300 tanaman.

\section{Pelaksanaan Penelitian}

\section{a. Pembuatan PGPR akar bambu}

Pembuatan PGPR akar bambu yang dilakukan terlebih dahulu yaitu mengumpulkan akar bambu bambu, kemudian akar bambu direndam dalam air selama 3 hari sebagai "Biang PGPR", setelah 3 hari semua bahan (gula merah, terasi, dedak, kapur) direbus dalam 20 liter air sampai mendidih kemudian dinginkan, rebusan bahan yang sudah dingin disaring kemudian campur dengan biang PGPR, bahan campuran disimpan dalam wadah tertutup dan diaduk sehari sekali, dan setelah 15 hari PGPR akar bambu siap digunakan (A'yun et al., 2013).

\section{b. Persemaian}

Persemaian awalnya yang dilakukan pemilihan benih yang baik, terlebih dahulu dilakukan yaitu perendaman benih pakcoy pada air hangat selama 5 menit, sambil merendam membuat media menggunakan baki dengan media tanah dan arang sekam dengan perbandingan $1: 1$, arang sekam di pilih karena steril dari jamur, setelah 5menit benih yang terapung di buang kemudian benih yang tinggal tenggelam di pindahkan pada media semai yang sudah di siapkan, kemudian di tutup dengan arang sekam. Lakukan penyiraman untuk menjaga menjaga kelembaban media persemaian dan tanaman. Bibit dirawat selama 14 hari (2 Minggu).

\section{c. Pengolahan tanah}

Pengolahan tanah sebelum ditanami, lahan digemburkan dengan cara dicangkul dengan kedalaman $30 \mathrm{~cm}$ selanjutnya tanah dibiarkan selama 3 hari untuk proses penguapan. Setelah 3 hari, tanah diolah kembali dengan menggunakan cangkul lalu bentuk bedengan $140 \mathrm{~cm} \times 140 \mathrm{~cm}$, luas parit $40 \mathrm{~cm}$ sedangkan panjang parit mengikuti panjang bedengan. Setelah itu bedengan sudah siap ditanami.

\section{d. Penanaman}

Pada tahap penanaman, bibit yang yang sudah berusia 2 minggu setelah semai sudah dapat dipindahkan pada media tanam yang telah dipersiapkan (bedengan). Penanaman bibit sebaiknya dilakukan pada sore hari. Jarak penanaman pakcoy yang digunakan yaitu $25 \mathrm{~cm}$ x $25 \mathrm{~cm}$ dan setiap lubang tanam ditanami 1 bibit tanaman pakcoy. Setelah penanaman lakukan penyiraman untuk menjaga kelembaban tanaman dan media tanam.

\section{e. Aplikasi perlakuan}

Pemupukan dilakukan dengan cara mencampurkan PGPR akar bambu sesuai dengan dosis. Menurut penelitian yang telah dilakukan sebelumnya (A'yun et al., 2013), aplikasi PGPR dengan konsentrasi $10 \mathrm{ml} / \mathrm{L}, 20 \mathrm{ml} / \mathrm{L}, 30 \mathrm{ml} / \mathrm{L}$ pada tanaman cabai rawit dapat meningkatkan 
produksi pada tanaman. Penelitian menunjukkan aplikasi PGPR dengan konsentrasi $30 \mathrm{ml} / \mathrm{L}$ berpengaruh nyata terhadap tinggi dan jumlah daun tanaman, dapat memaksimalkan jumlah daun dan tinggi tanaman pada tanaman tomat.

Pemberian PGPR akar bambu dilakukan ketika tanaman pakcoy berumur 7, 14, 21 dan 28 (HST), PGPR akar bambu diaplikasikan pada tanaman dengan cara di siramkan pada media tanam dengan menggunakan gembor, dengan menggunakan takaran sesuai dengan dosis yaitu $\mathrm{P} 1=10 \mathrm{ml} / \mathrm{L}, \mathrm{P} 2=20 \mathrm{ml} / \mathrm{L}, \mathrm{P} 3=30 \mathrm{ml} / \mathrm{L}$.

\section{f. Pemeliharaan}

Pemeliharaan tanaman terdiri dari penyulaman, penyiraman, penyiangan dan pengendalian hama tanaman. Penyulaman dilakukan pada tanaman yang kondisinya tidak memungkinkan memiliki pertumbuhan yang baik. Tujuan penyulaman untuk menggantikan tanaman yang layu, mati atau tidak tumbuh. Penyiraman dilakukan pada setiap pagi dan sore hari disesuaikan dengan kondisi tanah dan curah hujan. Sedangkan untuk penyiangan dilakukan apabila ada gulma di sekitar tanaman.

\section{g. Panen}

Masa panen pada tanaman pakcoy dilakukan setelah berumur 45-60 (HST). Tanaman yang telah layak panen memiliki daun yang tumbuh subur dan berwarna hijau segar, pangkal daun tampak sehat, serta ketinggian tanaman seragam dan merata. Proses pemanenan dilakukan dengan mencabut tanaman pakcoy dari dalam tanah (Abidin, 2015).

\section{h. Pengamatan}

Pengamatan dilakukan untuk memperoleh data yang akan dianalisis. Pengambilan data dilakukan 1 minggu setelah tanaman diberikan PGPR akar bambu dengan cara mengukur pertumbuhan tanaman dengan menggunakan alat ukur berupa mistar. Pengambilan data dilakukan pada saat tanaman berumur 7, 14, 21, dan 28 (HST), dilakukan sesuai dengan parameter yang diteliti, yakni: Tinggi tanaman, Jumlah daun, dan Berat basah.

\section{Analisis Data}

Data yang diperoleh dari pelaksanaan kajian dianalisis dengan menggunakan rumus model linear RAK (Sastrosupadi, 2009).

$$
\mathbf{Y}_{\mathrm{ij}} \quad \boldsymbol{=} \boldsymbol{\mu}+\mathbf{T i}+\mathbf{B}_{\mathbf{j}}+\epsilon_{\mathrm{ij} .}
$$

Keterangan:

$\mathrm{Y}_{\mathrm{ij}}=$ Respon atau nilai pengamatan dari perlakuan ke-i dan ulangan ke-j.

$\mu=$ Nilai tengah umum.

$\mathrm{T}_{\mathrm{i}}=$ Pengaruh perlakuan ke-i

$\mathrm{B}_{\mathrm{j}}=$ Pengaruh blok ke-j.

$\epsilon_{\mathrm{ij}}=$ Pengaruh galat percobaan dari perlakuan ke-i dan ulangan ke-j

\section{HASIL DAN PEMBAHASAN}

Hasil pengamatan pemberian PGPR akar bambu terhadap pertumbuhan dan produksi tanaman pakcoy dengan parameter yang diukur yaitu tinggi tanaman, jumlah daun pada umur 7 , 14,21 dan 28 hari setelah tanam (HST) dan berat basah yang dilakukan pada umur 45 Hari Setelah Tanam (HST) dapat dilihat pada table 1, 2, dan 3.

\section{Tinggi Tanaman}

Hasil pengamatan tinggi tanaman pakcoy terhadap pemberian PGPR akar bambu pada umur 7, 14,21 dan 28 HST dapat dilihat pada Tabel 1. Tabel 1 menunjukkan bahwa rata-rata tinggi tanaman pakcoy mengalami peningkatan pada umur 7, 14, 21 dan 28 hari setelah tanam. Umur 7 hari setelah tanam, P1 tidak berbeda nyata dengan P0 dan P2 tetapi berbeda nyata dengan P3. Umur 14 hari setelah tanam, P1 tidak berbeda nyata dengan P2 tetapi berbeda nyata dengan P0 dan P3. Umur 21 hari setelah tanam, P1 tidak berbeda nyata dengan P2 tetapi berbeda nyata dengan $\mathrm{P} 0$ dan $\mathrm{P} 3$. Umur 28 hari setelah tanam P0,P1,P2 sangat berbeda nyata dengan P3 Hasil sidik ragam dan uji BNT 0,05 pada umur tanaman 7 sampai dengan 28 HST.

Hasil sidik ragam pada tabel 1 menunjukkan rata-rata tinggi tanaman pakcoy umur 14 sampai 28 hari setelah tanam (HST) mengalami peningkatan. Hasil tinggi tanaman terbaik sampai dengan 28 hari setelah tanam diperoleh pada perlakuan P3 (PGPR akar bambu $30 \mathrm{ml} / \mathrm{L}$ air. Hal ini menunjukkan bahwa pemberian PGPR akar bambu memberikan pengaruh terhadap tinggi tanaman pakcoy. Hal ini sejalan dengan dengan hasil pendapat iswati (2012) menyatakan pemberian PGPR memberikan pengaruh nyata pada tinggi tanaman dan jumlah akar. 
DOI: $10.52625 /$ j-agr.v17i1.186

Tabel 1. Rata-rata tinggi tanaman (cm) pakcoy

\begin{tabular}{ccccc}
\hline \multirow{2}{*}{ Perlakuan } & \multicolumn{4}{c}{ Umur Tanaman (HST) } \\
\cline { 2 - 5 } & 7 & 14 & 21 & $21,27 \mathrm{a}$ \\
P0 & $5,90 \mathrm{a}$ & $7,90 \mathrm{a}$ & $15,60 \mathrm{a}$ & $22,67 \mathrm{a}$ \\
P1 & $6,19 \mathrm{a}$ & $8,67 \mathrm{a}$ & $16,90 \mathrm{~b}$ & $22,73 \mathrm{a}$ \\
P2 & $6,26 \mathrm{a}$ & $8,55 \mathrm{~b}$ & $16,69 \mathrm{~b}$ & $32,73 \mathrm{~b}$ \\
P3 & $6,31 \mathrm{a}$ & $9,50 \mathrm{c}$ & $19,23 \mathrm{c}$ & 1,51 \\
BNT 0,05 & th & 0,89 & 2,41 & $3,35 \%$ \\
KK \% & $11,25 \%$ & $5,16 \%$ & $7,06 \%$ &
\end{tabular}

Keterangan: Angka-angka pada kolom yang sama diikuti dengan huruf yang sama berarti tidak berbeda nyata pada taraf uji BNT 0,05.

Menurut Manulang et al,. (2014) unsur hara makro (N, P, K, Ca, Mg dan S) dibutuhkan tanaman dalam jumlah banyak oleh tanaman. Keenam unsur hara yang penting untuk tanaman adalah unsur hara N, P, dan K. Sehingga sokongan unsur hara dapat mendukung peningkatan produksi tanaman pakcoy. Ketersediaan Nitrogen (N) yang cukup akan mendorong pertumbuhan dan pemanjangan sel tanaman dengan baik sehingga $\mathrm{N}$ mempunyai peran penting bagi pertambahan tinggi tanaman. Hal ini sejalan dengan pendapat Nasution, F.J (2014) terjadinya pertumbuhan tinggi suatu tanaman karena adanya peristiwa pembelahan dan perpanjangan sel yang didominasi pada ujung pucuk tersebut. Azzamy (2015) dan Lindung (2014) menyatakan bahwa fungsi PGPR yaitu meningkatkan penyerapan dan pemanfaatan unsur N oleh tanaman. Lingga (2003) menyatakan bahwa peranan $\mathrm{N}$ penting dalam mendorong pertumbuhan vegetatif tanaman. Kekurangan unsur $\mathrm{N}$ mengakibatkan terhambatnya pembentukan atau pertumbuhan bagian-bagian vegetatif seperti seperti daun, batang dan akar.

\section{Jumlah Daun}

Hasil pengamatan jumlah daun tanaman pakcoy terhadap pemberian PGPR akar bambu pada umur 7, 14,21 dan 28 HST dapat dilihat pada Tabel 2. Tabel 2 menunjukkan bahwa ratarata jumlah daun pakcoy yang diamati mengalami peningkatan pada umur 7, 14, 21, dan 28 hari setelah tanam. Umur 7 hari setelah tanam P1 tidak berbeda nyata dengan P0 dan P2 tetapi sangat berbeda nyata dengan P3. Umur 14 hari setelah tanam P1 tidak berbeda nyata dengan P0 dan P2 tetapi berbeda nyata dengan P3. Umur 21 hari setelah tanam $\mathrm{P} 1$ tidak berbeda nyata dengan P0 dan P2 tetapi sangat berbeda nyata dengan P3 dan pada umur 28 hari setelah tanaman P3 sangat berdeda nyata dengan P0 dan P1. Hasil sidik ragam dan uji BNT 0,05 pada umur tanaman 7 , 14,21 dan 28 HST.

Tabel 2.Rata-rata jumlah daun tanaman pakcoy (helai)

\begin{tabular}{ccccc}
\hline \multirow{2}{*}{ Perlakuan } & \multicolumn{4}{c}{ Umur Tanaman (HST) } \\
\cline { 2 - 5 } & 7 & 14 & 21 & 28 \\
\hline P0 & $3,07 \mathrm{a}$ & $4,60 \mathrm{a}$ & $7,53 \mathrm{a}$ & $10,60 \mathrm{a}$ \\
P1 & $3,20 \mathrm{a}$ & $5,33 \mathrm{~b}$ & $8,00 \mathrm{~b}$ & $11,47 \mathrm{~b}$ \\
P2 & $3,40 \mathrm{~b}$ & $5,40 \mathrm{c}$ & $8,53 \mathrm{~b}$ & $11,53 \mathrm{c}$ \\
P3 & $3,80 \mathrm{c}$ & $6,00 \mathrm{~d}$ & $9,13 \mathrm{c}$ & $12,87 \mathrm{~d}$ \\
BNT 0,05 & 0,50 & 0,89 & 1,00 & 1,38 \\
KK \% & $7,48 \%$ & $8,32 \%$ & $6,02 \%$ & $5,96 \%$ \\
\hline
\end{tabular}

Keterangan: Angka-angka pada kolom yang sama, diikuti dengan huruf yang sama berarti tidak berbeda nyata pada taraf uji BNT 0,05 
Hasil analisis sidik ragam menunjukkan jumlah daun tanaman pakcoy pada umur 14-28 HST mengalami peningkatan. Peningkatan ratarata jumlah daun paling terbaik dapat dilihat pada umur tanaman 28 HST yang ditunjukkan oleh P3 (PGPR akar bambu $30 \mathrm{ml} / \mathrm{L}$ air) yaitu 12,87. Daun merupakan organ vegetatif tanaman yang digunakan sebagai tempat berlangsungnya fotosintesis. Fauzi dan Puspitawati (2017) menyatakan bahwa unsur hara $\mathrm{N}$ berperan penting dalam zat hijau daun (klorofil) yang sangat dibutuhkan dalam proses fotosintesis. Klorofil ini berfungsi sebagai absorben cahaya matahari yang digunakan dalam fotosintesis. Tanaman yang mendapat suplai $\mathrm{N}$ yang cukup akan membentuk helai daun yang luas dengan kandungan klorofil yang tinggi, sehingga tanaman dapat menghasilkan asimilat dalam jumlah yang cukup untuk menopang pertumbuhan vegetatif (Wijaya, 2008).

\section{Berat Basah}

Hasil perhitungan berat basah tanaman pakcoy terhadap pemberian PGPR akar bambu per perlakuan pada umur 45 hari setelah tanam (akhir kajian) dapat dilihat pada Tabel 3. Tabel 3 menunjukkan rata-rata berat basah tanaman pakcoy umur 45 hari setelah tanam. P1 tidak berbeda nyata dengan P2 tetapi berbeda nyata dengan P0 dan P3. Hasil analisis sidik ragam berat basah umur 45 HST.

Tabel 3. Rata-rata berat basah tanaman pakcoy 28 HST

\begin{tabular}{ccc}
\hline \multirow{2}{*}{ Perlakuan } & \multicolumn{2}{c}{ Berat Basah (Gram) } \\
\cline { 2 - 3 } & Total & Rata-Rata \\
\hline P0 & 105,67 & $55,8 \mathrm{a}$ \\
P1 & 109,33 & $55,94 \mathrm{a}$ \\
P2 & 108,00 & $58,20 \mathrm{~b}$ \\
P3 & 121,67 & $71,05 \mathrm{c}$ \\
BNT 0,05 & & 11,18 \\
KK \% & & $5,03 \%$ \\
\hline
\end{tabular}

Keterangan: Angka-angka pada kolom yang sama, diikuti dengan huruf yang sama berarti tidak berbeda nyata pada taraf uji BNT 0,05

Hasil analisis sidik ragam pada tabel 3 terhadap rata-rata jumlah berat basah segar tanaman pakcoy tertinggi terletak pada umur 30 HST dan di tunjukkan pada P3 yaitu 121,67 gram/tanaman. Pertambahan berat produksi pada umumnya disebabkan karena tingkat respon tanaman pakcoy terhadap pemberian PGPR dengan dosis $30 \mathrm{ml} /$ liter air merupakan yang terbaik dalam membantu penyediaan unsur hara $\mathrm{N}$, $\mathrm{P}$ dan $\mathrm{K}$ pada media tanam yang sangat dibutuhkan oleh tanaman dalam pertumbuhan dan perkembangan tanaman dalam memacu berat produksi tanaman.

Suhwayono (2011) menyatakan Asam humat hasil fermentasi bahan organik berfungsi menstimulasi pertumbuhan akar, merangsang pertumbuhan tanaman dengan cara mempercepat pembelahan sel dan meningkatkan berat tanaman. Lebih lanjut, Nurshanti (2010) menyatakan bahwa semakin tinggi tanaman maka semakin berat juga bobot tanaman tersebut, bahwa penambahan $\mathrm{N}$ yang sesuai kebutuhan akan membuat tanaman tumbuh dengan baik dan semakin besar tinggi tanaman serta jumlah daun maka berat basah tanaman semakin sawi meningkat.

Thakuria et al., (2004) berpendapat bahwa peranan PGPR dalam meningkatkan pertumbuhan dan produksi tanaman diduga ada hubungannya dengan kemampuan mensintesis hormon tumbuh. Isolat Bacillus sp. diilaporkan mampu mensintesis asam indolasetat (IAA) sedangkan Isolat $P$. Fluorescens selain menghasilkan IAA, juga menghasilkan sitokinin (Graciade Salamone dan Nelson, 2004). Adanya interaksi yang saling menguntungkan dengan cara pengembangbiakan bakteri yang ada pada akar bambu berdampak pada peningkatan pertumbuhan pada tanaman semakin tersedianya nutrien bagi bakteri PGPR maka bakteri PGPR akan sukses mengkoloni bagian akar tanaman sehingga dapat menguntungkan bagi pertumbuhan tanaman (Widyati, 2013). 


\section{KESIMPULAN DAN SARAN}

\section{Kesimpulan}

Aplikasi PGPR akar bambu memberikan pengaruh nyata terhadap pertumbuhan dan produksi tanaman pakcoy. Dosis $30 \mathrm{ml} / \mathrm{L}$ air (P3) menunjukan perlakuan terbaik dengan tinggi tanaman $32,73 \mathrm{~cm}$, jumlah daun 12,87 helai dan berat basah yaitu $121,67 \mathrm{~g} /$ tanaman.

\section{Saran}

Perlu adanya kajian lebih lanjut tentang penggunaan dosis PGPR akar bambu agar mendapatkan dosis yang lebih baik untuk meningkatkan pertumbuhan dan produksi tanaman pakcoy.

\section{DAFTAR PUSTAKA}

A'yun, K.Q., T. Hadiastono, and M. Martosudiro. 2013. Pengaruh Penggunaan PGPR (Plant Growth Promoting Rhizobacteria), Pertumbuhan, dan Produksi pada Tanaman Cabai Rawit (Capsicum frutescensL.). http://mitalom.com/pengertiandanfungsi pgprplantgrowthpromotingrhizobacteria.

Figuiredo. M.,Seldin. L. Araujo. F. \& Mariano. R. (2010). Plant Growth PromotingRhizobacteria:Fundamentalsa ndApplication.MicrobiologyMonograph $s(18)$ https://media.neliti.com/media/publ ications/237682-effect-of-plant-growthpromoting-rhizoba-f435cf1c.pdf

Iswati, R. 2012. Pengaruh Dosis Formula PGPR Asal Perakaran Bambu terhadap Pertumbuhan Tanaman Tomat (Solanum lycopersicum syn).Laboratorium Agroteknologi Fakultas Pertanian Universitas Negeri Gorontalo. http://digilib.uinsgd.ac.id/6147/4/4 bab 1.pdf/di.

Prasasti. D., E. Prihastanti dan M. Izzati. 2014. Perbaikan Kesubaran Tanah Liat dan Pasir dengan Penambahan Kompos Limbah Sagu Untuk Pertumbuhan dan Produktivitas Tanaman Pakcoy (Bracissca rapa var. Chinensis). Buletin Anatomi dan Ilmiah Peternakan. 1(1):365373.file:///C:/Users//Downloads /PERBAIKAN_KESUBURAN_TANA H_LIAT_DAN_PASIR.pdf/ diakses pada tanggal 25 Juni 2020.

Suwandi,2009. Menakar kebutuhan hara tanaman dalam pengembangan inovasi budidsys dsyursn berkelanjutan. Jurnal pengembangan inovasipertanian.2(2): 131147.https://media.neliti.com/media/p ublications/139945-efektivitas penggun aan-teknologi-pengelo 64ab9532.pdf

Wahyudi, A. T. 2009. Rhizobacteria Pemacu Pertumbuhan Tanaman: Prospeknya sebagai Agen Biostimulator \& Biokontrol. Nano Indonesia. file:///C:/Users// Downloads/568-16921-PB.pdf 